DOI: https://doi.org/10.21009/hayula.006.01.07

\title{
The Commodification of Religion in The 2012 Regional Election of Purwakarta Regency
}

\author{
Muhamad Ridwan Effendi \\ Islamic Education Departement, Faculty of Social Sciences, Jakarta State University \\ muhamadridwan@unj.ac.id \\ Surya Hadi Darma \\ Islamic Education Departement, STAI Dr.KH.EZ.Muttaqin Purwakarta \\ hadidarmasurya@gmail.com
}

Article Accepted: January 10, 2021, Revised: January 19, 2022, Approved: January 20, 2022

\begin{abstract}
This study aims to describe the involvement of religious instruments in the dynamics of the 2012 Regional Head Elections for the Regent and Deputy Regent of Purwakarta Regency. This research uses a qualitative method with the dramaturgical approach of Erving Goffman on symbolic interactionism and Max Weber on the theory of social action. This study indicates that the normative use of religious elements is used as a weapon for candidates as a political commodity to attract mass sympathy and highlight the identity of a particular group. Among the religious issues used in the Pilkada Purwakarta can be the use of religious symbols, culture, statements, primordial sentiments, figures and places used by the contestants and political constituents that occurred in Purwakarta.
\end{abstract}

Keywords: Religious Issues, Commodities, Politics, Conflict

\begin{abstract}
Abstrak
Penelitian ini bertujuan untuk menguraikan keterlibatan instrumen agama dalam dinamika Pilkada Bupati dan Wakil Bupati Kabupaten Purwakarta Tahun 2012. Adapun penelitian ini menggunakan metode kualitatif dengan pendekatan teori dramaturgi Erving Goffman tentang interaksionisme simbolik dan Max Weber tentang teori tindakan sosial. Hasil penelitian ini menunjukkan bahwa penggunaan unsur-unsur agama secara normatif dijadikan senjata bagi para kandidat sebagai komoditi politik untuk menarik simpati massa dan menonjolkan identitas suatu kelompok tertentu. Di antara isu-isu agama yang digunakan dalam Pilkada Purwakarta tersebut bisa berupa penggunaan simbol keagamaan, budaya, statement, sentimen primordialisme, tokoh dan tempat yang digunakan oleh para kontestan dan konstituen politik yang terjadi di Purwakarta.
\end{abstract}

Kata Kunci: Isu Agama, Komoditas, Politik, Konflik 


\section{Introduction}

Since the stipulation of the stages of the Pilkada of the Regent and Deputy Regent of Purwakarta Regency, the KPUD of Purwakarta Regency has determined three pairs of candidates for Regent and Deputy Regent who have been declared qualified as candidate pairs who will compete in the democratic event of the 2012 Regional Head and Deputy Regent Election of Purwakarta Regency. And the Deputy Regent, including: (1) Drs. In the future, H. Dudung Bachdar Supardi, M.M and H. Yogie Mochamad, SE., MM, referred to as DUGI and promoted by the parties supporting PAN, PPP and PKS; (2) H. Dedi Mulyadi, SH and Drs. Dadan Koswara, after this, referred to as SAHATE and promoted by the parties supporting Golkar, PKB, PDIP, Gerindra, Hanura and PDP; (3) Lt. Col. (Ret.) Burhan Fuad, SE., MM and H. Onnie S. Sandi, SE, after this referred to as BOMBER and carried by the Democratic party.

The 2012 regional elections for the Regent and Deputy Regent of Purwakarta Regency were a battleground for the political elite in their efforts to win the "heart" of the people to gain victory. However, in the process, the 2012 local elections for Purwakarta Regency did not go well and elegantly. For example, there are black campaigns and negative campaigns. The negative campaign itself is carried out by showing the mistakes and weaknesses of the political opponents, while the black campaign is accusing the opposing party with false accusations/slander that has not been proven or through things that are not relevant to his capacity as a leader, even this as an attempt to undermine or question political opponents by issuing negative propaganda.

As a form of negative campaigning in the 2012 Pilkada of the Regent and Deputy Regent of Purwakarta Regency, it was carried out by exposing weaknesses and failures by the opposing party to the incumbent Regent candidate, namely H. Dedi Mulyadi, SH, who was accused of failing to lead Purwakarta, corruption, the practise of money politics in buying and selling. Positions in the Purwakarta district government and increasing the amount of APBD debt for unclear development. As for the black campaign, accusations of inappropriate political opponents were directed at the incumbent Regent candidate, namely H. Dedi Mulyadi, SH, to become a leader because of his religion or race. Such a campaign was used as a political commodity for the pairs of candidates for Regent and Deputy Regent who competed for victory by bringing down each other through various ways and forms of commodification, which impacted the people of Purwakarta. 
Among the political commodifications that have an impact on the disintegration of the people of Purwakarta, the black campaign is the most dominant factor that appears marked by the presence of SARA elements in it, especially religious factors which are used as political commodification in the 2012 Pilkada of Regent and Deputy Regent of Purwakarta Regency. In the explanation above, it can be understood that the commodification of religion is a process of changing religious beliefs which are treated like goods or products that can be taken over by the market to be managed in such a way that they have a selling value and are suitable for consumption by the wider community.

In every pair of candidates or candidates who fought in the 2012 regional elections of Purwakarta democracy, of course, they had a successful team, one of which was to campaign for the vision, mission and programs of each candidate or pairs of candidates for the Regent and Deputy Regent of Purwakarta for the 2013 period. 2018. This success team has not emerged recently, although perhaps not in a concrete and specific form. The idea of a successful team has been around for a long time. It just does not appear openly. There are many ways that the candidates, through their success teams, use to influence and attract the sympathy of the masses, instead of using religion as a vehicle to convey their interests. For a developing society like Purwakarta, religion is a political commodity to attract the masses and a source of issues to attract sympathy and corner a specific group (Kahmad, 2011a).

Even long before the KPUD of Purwakarta Regency determined the three pairs of candidates for Regent and Deputy Regent of Purwakarta Regency who would compete in the 2012 Pilkada, the nuances of political interest based on religious issues seemed to be felt. This can be seen from the tragedy of the destruction of statues by using religion as a driving factor or motivation to carry out socio-religious actions. Of course, in this case, religion can be used as an instrument that can create conflict in society (Kahmad, 2011a). It is not even surprising that a public response states that statements like this always lead to an attitude of radicalism-extremism that will lead to a religious, political conflict that is fundamental to a particular religion (Smith, 1985). Thus, it becomes crucial in discussing the text of the results of this study.

In reality, the fundamental question of this research is to uncover religious issues in the regional elections, which will later lead to the relationship between religion and politics for today's society, although some parties have responded differently to the statements above. However, it is worth examining how much influence religious issues have in the Pilkada of Purwakarta Regency to encourage or increase vote acquisition for specific pairs 
of candidates. Because this inevitably becomes the discourse of various political campaigns that use religious issues as a strategy to win the votes of the voting public.

Each pair of candidates used the use of religious issues in the 2012 local elections in Purwakarta Regency, both symbols and statements. If the perspective of dramaturgy theory is used, the political behaviour of each candidate pair can be seen as a drama so that human actions depend on the time, place and audience they are facing (Kahmad, 2011b). The practice of campaigning through religious activities, for example, makes it a vehicle for the front stage where the candidate pairs will face and be seen by the religious community. This is done as part of the expectations and roles they play. While outside the campaign moment (backstage), the candidate pairs can get out of the image and scenario played out in each campaign (Kahmad, 2011b).

It is not without reason that Purwakarta Regency is used as research material. This is based on several considerations. First, Purwakarta is said to be a central city that automatically gives its colour and style to the diversity of the Purwakarta community. Second, since Purwakarta was under Regent H. Dedi Mulyadi, SH, polemics with religious nuances for some Purwakarta people have clashed with Islamic aqidah, especially since the majority of Purwakarta people are Muslim. One of the polemics was when the construction of statues of Sundanese puppet figures was considered against Islamic teachings. Third, in holding the 2012 Purwkarta Pilkada, not a few of the people of Purwakarta had disagreements and put each other down because of the candidate's pair of support, instead of religion being used as a justification tool to support and succeed the candidate pair.

Therefore, this research was motivated by the author's curiosity in obtaining theoretical clarity regarding the use of religious issues in the local elections so that the relationship between religion and politics in the development of today's society can be known. If the theoretical clarity has been obtained, it will facilitate a pure and objective assessment of the case of the 2012 Regional Head Elections in the Purwakarta Regency, which has always been associated with religious motives as identity politics.

The phenomenon of religious involvement in Pilkada politics can be realized by various symbols, actors and statements related to religion. This kind of phenomenon becomes essential in the context of regional autonomy and the Pilkada as a strategy to build democracy in local communities (Kahmad, 2011b). The influence of religion is evident in the current era of regional autonomy, especially in the Pilkada of Purwakarta Regency. This 
kind of fact can also be seen from the history of Indonesian politics when religion played or was played as a political force (Kahmad, 2011b).

The view that religion and politics are like this is also influenced by the idea that religion is no longer a "private" issue but instead has a "public" character. This means that religion contains more values related to the public benefit, such as its encounter with politics. Thus, when religion is empirically linked to social and social issues, tensions are often found between the two areas, both religion and politics, as part of life's problems.

However, not all statements that religion and politics have a relationship are confirmed by some of the parties above because there are opinions that suggest that there is no involvement of religion in practical politics. This opinion assumes that politics has a different area, even contrary to religion (Kahmad, 2011b). Therefore, religion is private, while politics is something other than religion.

According to Bahtiar Effendy, those who support the view that religion is not separated from worldly problems, whether social, cultural, or political, are associated as adherents of scriptural or fundamentalist religions, while those who support the opinion that religion is entirely unrelated and therefore must be separated are those who who have a secular life attitude (Effendy, 2000). However, as mentioned earlier, the views that give rise to counterproductivity need to be addressed because they will impact changing one's behaviour in religion and society.

The practice of using religious issues in politics varies considerably. Both symbols, places, and statements of primordial sentiments are used. In this context, religious issues in campaigns are based on the belief that the public will give their political choices to pairs of candidates who have excellent and correct religious qualities. For this reason, each pair of candidates tries to portray themselves as religious, even if necessary, to manipulate them (Kahmad, 2011b). However much politics can play the role of religion in people's lives in both developed and developing countries, the commodification of religion in politics will continue to give rise to conflict or disagreement. It is just that the temperature of the conflict sometimes weakens and sometimes strengthens, depending on political dynamics, where the ruling party's behaviour towards his political opponent will determine the temperature of the conflict (Mintarja, 2011). 


\section{Research Method}

In this study, the authors use descriptive qualitative methods with data collection techniques through interviews with the success team, supporting political parties, community leaders, religious leaders, community organizations, NGOs, and election organizers such as KPU and Bawaslu, as well as reviewing documentation of other sources such as the mass media that occurred within the socio-cultural scope of the Purwakarta community during the 2012 local elections for the Regent and Deputy Regent of Purwakarta Regency - then analyzed by data triangulation technique using relevant theories in this study such as Erving Goffman's dramaturgy theory of symbolic interactionism and Carl G. Jung's theory of social action.

\section{Research Finding}

\section{Socio-Cultural Society of Purwakarta Regency}

Purwakarta Regency is part of West Java Province which is located between $107^{\circ} 30^{\prime}$ $107^{\circ} 40^{\prime}$ East Longitude (BT) and $6^{\circ} 25^{\prime}-6^{\circ} 45^{\prime}$ South Latitude (LS) (Statistics, 2015). Based on the location of the area, the boundary line of Purwakarta district covers the western part, and part of the northern part is bordered by Karawang district, the northern part and part of the eastern part is bordered by Subang district, the southern part is bordered by West Bandung district, the Southwestern part is bordered by Cianjur district, and the southern part is bordered by West Bandung regency. Bogor.

Administratively, Purwakarta Regency, since January 2001, has 17 sub-districts consisting of 192 villages, and 9 of them are sub-districts. Most of the Purwakarta district residents choose to live in the Purwakarta sub-district. This is because the Purwakarta subdistrict is the centre of the city and the district government, rich in facilities needed by the community. Apart from that, the Purwakarta district is at the meeting point of three main traffic lanes that are very strategic, namely the Purwakarta-Jakarta, Purwakarta-Bandung and Purwakarta-Cirebon routes which are the main routes of the North coast (Pantura) to the east of Java.

The condition of the people in Purwakarta Regency can be categorized as a religious community that is less permissive towards religious matters, and this can be seen from the number of religious cases leading up to and during the Pilkada Regent and Deputy Regent of Purwakarta Regency. The reason is that religion is considered sacred and should not be used as a game and a material for ridicule for everyone, including making it a commodity to 
achieve the interests of specific individuals or groups. Based on the population census data based on their religion, the majority of the people of Purwakarta are Muslim. The last census said 99.18 per cent, while Christians (Catholics and Protestants) were 0.61 per cent, Hindus were 0.05 per cent, and Buddhists were 0.12 per cent—others (Konghuchu, Tao) 0.04 per cent (Statistics, 2015).

In summary, the long history of Purwakarta's leadership journey changed when regulation was enacted regarding the limitation of the term of office of regional heads to a maximum of two leadership periods; finally, the Regent of Purwakarta got a new leader, namely Drs. H. Bunyamin Dudih, S.H., served as the eighth and ninth Regent of Purwakarta. He served for two terms, namely the first period from 1993 to 1998, where this period was under the New Order regime. Furthermore, the second period 1999-2003, was a transitional period for the reformation order, which began in 1997, at this time, it opened the door to Indonesian democracy, so Drs. H. Benjamin Dudih, S.H. was elected as the second Regent in Purwakarta district, which was held by General Election (Pemilu), in which the community was directly involved in making their choices in a direct, free and secret manner. In addition, it is also a cover for the leadership of the regional head with an official from the Regent.

The first general election during the reformation order that led to Bunyamin Dudih did not escape the desire of people to become regional heads in the Purwakarta district. In the second election in this reform era, Drs. H. Lily Hambali Hasan, M.Si as the tenth Regent of Purwakarta, and for the first time has a Deputy Regent, namely H. Dedi Mulyadi, SH (2003-2007). In this period, the leadership of the Purwakarta district looked different. In addition to having a representative to accompany the Regent, Purwakarta district's strategic development measures have also increased. Although, on the other hand, the methods are taken by the regional head, both the Regent and the Deputy Regent differ in their leadership styles.

The first general election during the reformation order that led to Bunyamin Dudih did not escape the desire of people to become regional heads in the Purwakarta district. In the second election in this reform era, Drs. H. Lily Hambali Hasan, M.Si as the tenth Regent of Purwakarta, and for the first time has a Deputy Regent, namely H. Dedi Mulyadi, SH (2003-2007). In this period, the leadership of the Purwakarta district looked different. In addition to having a representative to accompany the Regent, Purwakarta district's strategic 
development measures have also increased. Although, on the other hand, the methods are taken by the regional head, both the Regent and the Deputy Regent differ in their leadership styles.

\section{Identity and Platform of the Contestants for the Election of Purwakarta}

Election contestants, especially the 2012 elections for the Regent and Deputy Regent of Purwakarta, have confirmed that they will register the candidates first with the KPUD of Purwakarta Regency. Once registered, they are declared valid as candidates. Once registered as candidates, they are invited to package patterns and various campaign agendas. At times like this, usually, pairs of candidates tend to offer their respective promises to gain support in the election of the Regent-Deputy Regent of Purwakarta.

When the promise or what they (read; contestants) called the vision or platform has been made, then socialization through campaigns is one way to convey the platform. Furthermore, the community as a political constituency will pay close attention to the platform's contents so that later the votes cast will positively impact the broader community. When looking at the promises of each candidate, the public as political constituents can easily read that the socio-cultural background (social origin) of each candidate is closely related to what their political behaviour is. This is easy to understand because, as psychoanalysts argue, the vision or platform made by the candidates is a reflection or function of the archetype- or one's conscious mind. This means that vision is a reflection of the most profound state of the soul as a result of the crystallization of experiences that are built by each person and will be used both consciously and unconsciously to respond, define and shape their lives (Effendi, 2020b; Jung, 1964).

In reading the archetype of each contestant, the candidate's background for the Regent-Vice Regent of Purwakarta is certainly interesting to note. The candidate pairs for the DUGI, SAHATE and BOMBER coalition are an identity that the public must understand because this will affect the constituents' perceptions of each candidate's identity and platform.

Many thinkers such as Ericsen, Picard and Giddens argue that no group of people in this world does not have an identity. Because identity is a prominent distinguishing "tool" between one group and another (Hanani, 2011). According to Lan (2000), each individual needs an identity that will give him a sense of belonging and social existence (Hanani, 2011). Therefore, this identity will appear in every social interaction, called social identity. Identity 
is usually marked by symbols, behaviour, culture, and religion. In fact, in a global context, religion is also increasingly becoming and strengthening a symbol of the identity of a group. Religion is one form of social identity. Thus religion is unique when there is a collection of various identities.

Under the conditions of the same individual identity as this, it can provide benefits that then lead to the formation of religious communities ((trans.), 2012). This social identity in religion will also clearly become a debate and an arena for conflicts or clashes that will never go away. Seeing this kind of thing, identity is elementary to bring into the realm of conflict, and identity is also elementary to "disrupt" harmonious relations between religious communities. Some negative assumptions also emerged, and it was pointed out that religion was a "scapegoat" for the emergence of divisions and even hostility in the development of today's life. Religion, which should be used as a means of community control, is accused of causing unrest and is always in conflict with changes in the modernity of life (Grose, 1998).

The religious identity inherent in every human being cannot be separated in various aspects of life, one of which is in the world of politics, including the Pilkada of Regent-Vice Regent of Purwakarta Regency. As I quoted in Carl G. Jung's statement, to be able to understand the identity of each individual, it is necessary to have a specificity as a differentiator from other individuals, even in the practical politics of the Purwakarta Pilkada, the difference will be seen in contrast to the platform used by each candidate. The platform or vision and mission, continued Carl G. Jung, reflects the most profound mental condition as a result of the crystallization of experiences that are built by each person and will be used both consciously and unconsciously to respond, define and shape their lives.

In the Purwakarta Pilkada stage, there is an agenda for delivering the vision and mission of each candidate. Seeing Carl Jung's statement, this needs to be done because by conveying the vision and mission, the public will know better about the leader they choose. The delivery of the vision and mission of the three pairs of candidates for Regent and Deputy Regent of Purwakarta was held at the plenary session of the Purwakarta DPRD. Previously, the three pairs read the "Declaration of Peace" guided by the Chairperson of the Purwakarta KPU, Deni Ahmad Haidar, and then continued signing on a large charter. As the author also witnessed, the chairman of the Purwakarta DPRD, Ucok Ujang Wardi, in his speech said, "the presentation of the vision and mission at this plenary session marks the start of the campaign period for the three pairs of candidates for Regent and Deputy Regent of Purwakarta 2013", he further revealed, "all manuscripts The vision and mission read by the 
pairs of candidates for Regent and Deputy Regent will become a document for the Purwakarta DPRD so that whoever is later elected, we will reopen the document" (Wardi, 2012).

Here are the identities and platforms of the candidates for the Purwakarta RegentVice Regent candidate pair in the 2012 Purwakarta Regional Head Election to get to know more.

\section{DUGI Coalition Candidate Pair}

The candidate pair for the DUGI coalition is Drs. H. Dudung Bachdar Supardi, MM paired with H. Yogie Mochamad, SE., MM. This pair was joined by a coalition of three parties, namely the United Development Party (PPP), the National Mandate Party (PAN) and the Prosperous Justice Party (PKS). Candidates for Regent of the DUGI coalition, namely Drs. H. Dudung Bachdar Supardi, MM, is the Deputy Regent who accompanied the incumbent Regent candidate in 2008-2013.

The DUGI coalition platform is as follows:

Vision : "The Realization of a Religious, Democratic, Intelligent, Advanced and Prosperous Purwakarta and a Trust in Unity for Purwakarta Wibawa Karta Raharja"

Mision : 1. Encouraging the creation of a religious, noble and civilized society;

2. Prioritizing deliberation by taking into account the opinions of religious and community leaders;

3. To educate people's lives that are oriented towards imtaq and science and technology as well as to promote the people's economy through the construction of infrastructure and the creation of a conducive working and business/investment climate;

4. Creating physical and spiritual well-being for the entire community of Purwakarta;

5. Protect and serve the people of Purwakarta in a trustworthy, fair, honest and complete sense of responsibility for the sake of unity and unity/groups without discriminating against ethnicity, religion and race.

The DUGI coalition, supported by PAN, PPP, and PKS, read out the vision and mission text entitled "Purwakarta Design: Strategic Steps to Straighten Purwakarta" before the participant's plenary session of the Purwakarta DPRD. In the platform, it can be seen that religious values are contractedly mentioned in it. Likewise, as said by Deni Ahmad Haidar, the chairman of the KPUD Purwakarta, when he was met at his office explaining (Haidar, 2012), "Each pair of candidates is required to submit their candidacy data or files to the 
$K P U$, including the platform. The candidates need to carry out this in the interest of the KPU to socialize the goals and steps taken by each candidate or supporting party".

\section{SAHATE Candidate Pair}

The candidate pair for the SAHATE coalition is H. Dedi Mulyadi, SH, paired with Drs. Dadan Koswara. This pair is supported by a coalition of five parties, namely the Golkar Party (Golkar), the Indonesian Democratic Party of Struggle (PDIP), the National Awakening Party (PKB), the Greater Indonesia Movement Party (Gerindra), the People's Conscience Party (Hanura) and the PKPI Party. The Regent of the SAHATE coalition, namely H. Dedi Mulyadi, is the Regent of Purwakarta for the 2008-2013 period, which is also the candidate for Incumbent Regent in the Pilkada of Purwakarta.

The SAHATE coalition's platform is as follows:

Vision : "Purwakarta with character is an integrated development pattern based on the compounding of the basic values of land, water, air and sun as the basis for human creation which is reflected in the life order of the community which has the meaning of oneness towards the glory of life as a form of human responsibility as special beings."

Mision : 1. To develop development based on local wisdom with religious values, oriented towards excellence in education, health, social welfare and equitable economic distribution for the entire community;

2. Development of regional and spatial structures oriented towards environmental integrity both upstream and downstream as well as elements of soil, water, air and sun;

3. Develop a government structure that is oriented to the satisfaction of rural-based public services oriented to the people's prosperity.

\section{BOMBER Coalition Candidate Pairs}

The BOMBER candidate pair is Lt. Col. (Ret.) Burhan Fuad, SE., MM. paired with H. Onnie Soerono Sandi, SE. This pair is only carried by one party, namely the Democratic Party. The BOMBER Regent candidate, namely Lt. Col. (Purn.) Burhan Fuad, SE., MM was a candidate for Regent in the 2007 Purwakarta Pilkada, where his political rival was H. Dedi Mulyadi, SH who was paired with Drs. H. Dudung Bachdar Supardi, MM. BOMBER coalition platform:

Vision : "Returning Purwakarta to its identity as a multicultural area; that mutually tolerate each other, to create a government that is ka'fah"

Mision : 1. Building Human Resources who are healthy, intelligent, and have faith in Allah Subhanawata'ala; 
2. Creating a clean government;

3. Revitalizing the bureaucracy through the principle of transparency or openness;

4. Raising the Purwakarta Community Development Index (IPM) to a better condition;

5. . Improving public service programs through education, health, and maternal and child welfare;

6. Creating a healthy and responsible democratic climate;

7. Open space for the public to get as much information as they want..

In the BOMBER coalition platform, the priority is on work programs to increase per capita income and the human development index (IPM) of the Purwakarta community, which is far behind compared to other districts in West Java. In addition, the platform also contains religious values.

After all, the platforms used by each candidate have the same values and goals to advance Purwakarta in the future, but if we examine more deeply, some of the candidate platforms have religious influences that can be used as a reference for each candidate to win the hearts of the people of Purwakarta. As revealed by Deni Ahmad Haidar (Haidar, 2012):

"The vision, mission or program offered by each candidate is a force that will be used as a tool to win voters' votes. Therefore the platform he uses must be smartly packaged in the frame of the desire and reading of the conditions of the people of Purwakarta."

Departing from the platform used by the candidates, it seems that the platform with religious influence has received serious attention from the people of Purwakarta. The reason is, it can boost the popularity of one candidate, calling it the DUGI coalition. The platform he uses has a strong religious influence, and many of their political readings on the condition of Purwakarta are used as issues or public opinion for imaging to gain the votes of the constituents of the Purwakarta community.

However, it seems different and does not even match the predictions as expressed by Rohendi, whom I met on the sidelines of his busy work and explained that (Rohendi, 2012):

"In this Purwakarta Regional Head Election, it is possible that predictions will occur in two rounds. This is because the two poles of political power in the Pilkada Purwakarta, namely the DUGI and SAHATE coalitions, become a magnet for the community to determine the choice of leaders who are considered capable of bringing Purwakarta forward. However, this may not be because the strength of the Incumbent SAHATE candidate for political communication has been carried out long before the Purwakarta Pilkada, for example, through the Gempungan media, so that the public already knows the figure of the leader they will choose in the future." 
It turns out that this is proven to be accurate, the DUGI coalition which often creates an image of itself to boost voter votes with the issues it throws at the community through the statue issue movement with a series of issues related to religion, precisely in the results of the election held on Saturday, December 15, 2012, unable to compete with the votes acquired by the candidate pair for the SAHATE coalition. The votes obtained by SAHATE were twice that of the DUGI coalition.

\section{Articulation of Religious Issues in Purwakarta's Political Arena}

Social conflicts had indeed occurred long before implementing the 2012 Purwakarta Pilkada began. Moreover, the current globalization had begun to affect the people of Purwakarta in general. In conditions like this, it is usually used as a source of reference for the community and local government to improve every line of life, especially the mentality of the Purwakarta community, so that various social conflicts, both vertically and horizontally, do not occur. There are many different ways, especially the Purwakarta district government, to implement various strategies in resolving these various social, economic and political conflicts, for example, the village activity which is carried out once a week which is intended so that the local government can see firsthand the complaints and obstacles faced by the community which then used as a reference for every policy issued by the local government.

In these gempungan activities, it looks different. It even becomes the hallmark of the Regent of Purwakarta, who is also one of the incumbent candidates in the Pilkada Purwakarta, usually holding wayang golek performances. Besides being considered to have many philosophical and moral values conveyed to the public, wayang golek performances are also relatively orderly entertainment in the sense that there are almost no sources of horizontal conflict that occur.

Gempungan has a positive value for some observers and reasonably thick political content. The reason is that every time there is a puppet show, the Regent always calls small children or the elderly (elderly) to have a dialogue about their daily life or their assessment of development in Purwakata, course after the dialogue is almost over, the Regent then gives appreciation in the form of money or a goat to raise.

Apart from that, Purwakarta development policies issued by local governments often trigger vertical conflicts. Infrastructure development in Purwakarta is considered good because almost all city streets or every corner of the alley have been hot mixed. However, 
some areas have not been hot mixed, usually because of the vote factor during the first regional election, finally. For areas with low voter turnout, conditions tend to be poor. The path is not yet in the hot mix. This phenomenon occurs not only in the Purwakarta district but has even become a socio-political disaster in Indonesia.

Another policy that is no less important and becomes an issue in the Pilkada Purwakarta is the case of erecting wayang statues in every corner of the city of Purwakarta, which is considered contrary to Islamic law and the religious traditions of the Purwakarta community. This government policy has become a vertical conflict between the government and the community who reject such a direction of Purwakarta development. In addition to vertical conflicts, the pros and cons between a community and another community over the government's policy sparked a lengthy dispute that led to the implementation of the Pilkada Purwakarta.

Talking about issues can be interpreted as material for a debate, subject of dispute, hearsay, or rumours (Kamarulzaman, 2005). Issues are part of public opinion, and this is what Cutlip and Center say that public opinion is the accumulation of individual opinions about an issue in open discussion and affects a group of people. Thus, public opinion is formed through activity in the form of debate, conversation, or the exchange of information between individuals in a group (Lippman, 1998). Apart from that, the issue can also be interpreted as a problem. Therefore the problem is also part of public opinion. Clyde stated that public opinion is a social assessment of an important and meaningful issue based on conscious and rational exchanges by the audience (Lippman, 1998). Thus, an issue is an event, problem or event that can be predicted to occur or not occur in the future, which involves economic, social, political, legal, or religious matters.

The use of Max Weber's theory of social action is used as a lens to see how the political behaviour of the people of Purwakarta in the 2012 Pilkada was seen from their religious motives, which were able to encourage the emergence of political expression wrapped in religion which was considered as something sacred, but easy to use as a tool of political propaganda. . The emergence of religious issues in the Pilkada of the Regent and Deputy Regent of Purwakarta with their various forms and symbols is a sign of the commodification of religion. It makes religion a motive or impetus for practising political interests, as happened during the campaign by each pair of candidates.

As for Erving Goffman's dramaturgical theory, in the discussion of this research, it was found that there was a role for the parties involved who deliberately divided the front 
stage and backstage to make religious issues a black campaign by political elites to achieve goals. Certain. In the front stage area, it can be seen from platform pairs of candidates who carry elements of religion or belief, statements of primordialism of supporters or sympathizers who tend to use religion and race as political tools. Whereas in the backstage area, each candidate pair and supporting party did not claim that what happened in the case of violence and hate speech in the 2012 Purwakarta Regional Head Election did not see it as a religious conflict, but rather on excessive political expression and for some people or supporters as a voter, this kind of strategy is considered effective in boosting the vote of voters who are in the irrational category, because the people of Purwakarta as voters still have religious sensitivity, so they are easy to invite when using issues related to religion.

Based on the differences in the political behaviour of religious communities as described above, the typology of voters can be distinguished based on the level of diversity in religious communities (Mukhlis, 2008). First, a society whose religion is dominant and an ideological political attitude model emerges, meaning that religious communities treat politics the same as attitudes in religion. Second, the community where religion is personified in the figure of religious leaders so that a charismatic political behaviour model appears, meaning that the religious community chooses the candidate for Regent and Deputy Regent as leaders in Purwakarta in the future on following the attitudes and behaviour of someone they admire. Third, the rational model, meaning that the political ability or attitude of the religious community in selecting the candidate pairs for the Regent and Deputy Regent of Purwakarta Regency, is based on considerations of rational ability. They usually choose or not vote based on the ability of each pair of candidates to offer programs that can improve or fight for the fate of the community.

\section{Forms of Religious Issues in the Pilkada of Purwakarta Regent-Deputy Regent}

The people of the Purwakarta district are religious communities, especially the majority of the population is Muslim. The religious style practised in social, economic, cultural and political activities is based on Ahlussunnah wal Jama'ah (Effendi, 2021c). The traditional orthodoxy of religious values is used as an attitude of life for people raised in Islamic society (Razak, 2012). It was borrowing Gus Dur's term, the tradition of religious values that appears like a sub-culture that always colours daily life activities in the Purwakarta district, even in its intersection with the political realm (Effendi, 2020b). When 
religion becomes energy in this life, it is not easy to separate religion from the things that exist in everyday life. Even in a secular state, religious elements are considered for practical political purposes and tend to be instrumentally used as a means of justifying political and religious actions rather than as a factor of purposeful value (Maliki, 2010).

The heterogeneous social conditions of the Purwakarta community give rise to a variety of contrasting differences between a society in certain areas and other areas. Call it between rural and urban communities or indigenous peoples and immigrants. In this context, ideally, every community can accept differences. However, the reality can be seen as the occurrence of social conflicts. This is because rural or urban communities and natives and immigrants highlight each other's identities as a form of their existence. In his book The End of History and The Last Man, Even Francis Fukuyama mentions that identity is elementary to bring into the realm of conflict, even an identity too. Very easy to use as a tool to "disrupt" the harmony of social relations (Fukuyama, 2007).

This study related to identity is a characteristic building played by every human individual, even according to Ericsen (1993), an identity can be reconstructed or formed by ourselves (Hanani, 2011). Referring to the identity theory, of course, in the process of implementing the regional head elections (Pilkada) for the Regent and Deputy Regent of Purwakarta Regency, there is also a requirement for this kind of social conflict to occur, in which each pair of candidates or candidates who compete with supporting parties, success teams and sympathizers highlight each other's identities or symbols that serve as the legitimacy of public opinion (Nimmo, 2010).

Ketika opini publik telah disusun sedimikian rupa oleh setiap kandidat, maka hal itu akan menjadi isu yang mesti dimiliki bersama secara luas oleh para pendukungnya melalui kegiatan kolektif sebagai usaha komunikasi politiknya. Demikian juga suatu isu akan mulai dirasakan seutuhnya ketika dikomunikasikan dari satu orang kepada orang kedua, yang kemudian dilanjutkan dalam percakapan individu setiap orang untuk mengukur pengaruh dan mempertimbangkan isu tersebut. Di antara isu-isu yang dijadikan opini publik dalam Pilkada Purwakarta tersebut adalah sebagai berikut :

\section{The use of certain public opinions to create a negative impression of one of the pairs of candidates for the Regent-Deputy Regent of Purwakarta}

The use of public opinion like this occurs in several forms of issues, first, accusations of disbelief against one of the candidates, namely SAHATE because it has 
never been seen praying in the congregation; second, the candidate for Incumbent SAHATE has created polytheism by erecting many statues in Purwakarta which are considered contrary to Islamic teachings; Third, the candidate for Incumbent SAHATE does not want to stay in touch with the ulama, especially in villages.

Several informants also confirmed the three types of issues. As stated by Asep Saepudin, that (Saepudin, 2012):

"The implementation of the Pilkada Purwakarta was deemed to have gone smoothly and successfully, although the journey was marked by disagreements between supporters of the candidate pair for Regent and Deputy Regent regarding the accusations against the incumbent candidate pair who were considered to have departed from Islamic Shari'ah on the grounds of erecting many puppet statues in the corner. -corner of the city of Purwakarta".

Reading the theory of issues and the reality of the Purwakarta Pilkada is often used as an opportunity for interested groups to overthrow the Purwakarta Regent's policy which is considered political and ignores religious norms. Until the implementation of the Pilkada Purwakarta, the local government policy, in this case, the Regent of Purwakarta, who is also the incumbent candidate, was accused of violating religious norms. Even according to Jalaluddin (Jalaludin, 2013),

"The incumbent candidate is called the father of idols because he has erected many statues, until one day there was a DUGI sympathizer who stated that anyone among the people of Purwakarta who chose the SAHATE partner as an incumbent candidate had entered a circle of polytheism and would even end up in a state of polytheism. apostasy"

The socio-cultural society of Purwakarta is religious, tends to see new things, especially not from religious values, mainly because the majority of the people are Muslims who always give a negative response. This can be seen from destroying the statue by Muslims as a form of anger from the Muslim community over the Regent of Purwakarta, who always acts like a non-Muslim. The Pastebin Council" said, "many people when they hear music, whether it be songs or flute, harp and other instruments, are more solemn in listening than when they hear children reciting the Qur'an, praising in the surau or when the call to prayer is sounded". For some people who attended the recitation, Jalaluddin continued, this statement was interpreted as a form of blasphemy by equating the position of the Koran with the flute and the harp (Jalaludin, 2013). 
In the Pilkada Purwakarta, according to Asep Amidin, who is also a member of the DUGI success team said (Amidin, 2013):

"The most dominating issue that has become the talk of the community is related to statues/idols that stand tall even though they have been torn down by several Islamic organizations such as FPI, FUI, the Indonesian Mujahideen Council and the Islamic community who are against the Regent and the statements of the incumbent candidate while serving as Regent which is understood society as a form of blasphemy against religion by equating the position of the Koran with the flute and the harp."

However, it is different from Supriyanto's statement, a Buddhist (Supriyanto, 2012) that, "I do not see that there is an element of religion that is used as an issue in the various Purwakarta Pilkada campaigns, but it is a form of people's misunderstanding of the culture and direction of Purwakarta development which is then associated with religious issues so that there is a clash with one religion."

The above phenomenon illustrates the sensitivity of the relationship between religion and politics. This sensitivity comes to the surface mainly because some variables explain each other. One of them is the variable that the Regent of Purwakarta, an incumbent candidate, has issued policies that are not based on certain religious norms, namely Islam, even the incumbent candidate is seen as a new idol bearer in Purwakarta. This relationship between political and religious variables later becomes the public's attention.

\section{The use of the religious doctrine in the candidate platform}

In this category of public opinion, the issue used is the issue of developing a religious community and improving the welfare of the community's moral guides, including religious leaders, namely ulama. The use of this kind of religious doctrine can be seen in the platform for the DUGI and BOMBER coalition candidates.

In contrast, the platform mentions religious language as a part of using religion as a medium to influence society (Effendi, 2021b). For example, the platform for the DUGI coalition candidate pair reads "Encouraging the creation of a religious, noble and civilized society", or the BOMBER coalition candidate pair, which reads "Building healthy, intelligent, and faithful Human Resources in Allah Subhanawata'ala.”

In the Pilkada Purwakarta, the delivery of the vision and mission of each candidate absolutely must be done. Because according to Carl G. Jung, by conveying the vision and 
mission, the public will know more about the figure of the leader they choose. Submission of the vision and mission of the three pairs of candidates for Regent and Deputy Regent of Purwakarta was formally socialized in the plenary session of the Purwakarta DPRD. Then to socialize the platform, the candidates build steps through various media such as in newspapers, television, Baligho, posters, banners and others.

\section{Campaigns on visits to places that are considered religious symbols}

In their efforts to win the Purwakarta Pilkada, the candidates did not hesitate to suddenly approach nodes that could bring in supporters to boost vote acquisition, including firstly, attending the recitation of the ta'lim majlis among Muslim women; Second, visiting Islamic boarding schools; Third, go to the monastery; Fourth, attend religious activities.

Another thing that also attracts public attention is that some religious figures and leaders jointly play these religious and political variables. As stated by Nunun Nurhidayah, whom the researcher met on the sidelines of her busy life as a religion teacher at one of the junior high schools in Bojong, also Cica Pujianti, a housewife who is active in the recitation of the ta'lim assembly, explained that (Pujianti, 2013):

"There are several kyai or clerics when during the recitation for mothers, the ustadz indirectly leads the congregation to choose one candidate pair who has a strong personality and religion or "Nyantri" and this is evidence that religious leaders can easily be used as tools in the implementation of the campaign because it has a mass base".

The cultural tendencies of the motives experienced by Cica and Nunun are often exploited by the political elite and religious leaders involved in the Pilkada. So it is not surprising when many religious activities with political nuances are held just to attract the sympathy of the religious community as voters, such as in commemoration of religious holidays, recitation activities and so on. The involvement of political elites in playing the role of religion is felt to be able to increase popularity, as well as acceptability or eligibility to be accepted by touching the emotional side of religious people with the intention that what is desired can be realized (Effendi, 2020b; Kahmad, 2011b). This kind of strategy is considered effective in boosting the vote of voters who are in the irrational category (Muchlis, 2008) because the people of Purwakarta as voters still have religious sensitivity, so they are easy to invite when using issues related to religion.

Ko Anyih, a Buddhist, once told the researcher that (Nata, 2012): 
"The Incumbent SAHATE candidate once came on the sidelines of our religious activities, although he did not directly explain his purpose to ask for support from the people who were present at that time, some of us considered this purely in his interest as a professional bureaucracy to attend to fulfil the invitation that we sent out earlier."

\section{Use of religious arguments to legitimize specific candidates}

One form of the issue used is the prohibition on electing leaders who have left the Islamic creed because they have tarnished religion by erecting statues.

There is an interesting statement from one of the pairs of candidates for DUGI in the Pilkada of the Regent and Deputy Regent of Purwakarta, which is considered a confrontation against one of the pairs of candidates for the Incumbent, SAHATE. In the statement, Fauzan al-Ghifari also confirmed the use of a slogan by DUGI sympathizers, which reads, "Let us get it straight! return to the Islamic faith" (Al-Ghifari, 2013). This brings up religious issues to direct and take the sympathy of the people of Purwakarta to support and elect him as Regent and Deputy Regent of Purwakarta Regency in the upcoming 2013-2018 period.

A similar statement containing religious elements was also made during the DUGI campaign in the Plered sub-district. DUGI campaigner, Zaenal Abidin, in his speech, said that the Purwakarta Pilkada this time was a war against evil. The reason is, it is clear that his current political opponent is a party whose policies have often caused controversy in the community for the past five years. Even Fauzan and Eka, who were involved in the DUGI campaign at that time, said more than that, the incumbent candidate for the SAHATE coalition tends to keep people away from Islam (Purnama, 2012).

As also reported by the general daily newspaper Radar Karawang, when DUGI campaigned in Plered, Zaenal also insinuated many cases in Purwakarta that were known to have captured the attention of Purwakarta Muslims - starting from pasting photos on the Koran, simulating a flute (musical instrument) with the Koran to making statues. Zenal said, "Now is the time for us to fight and win the war" (Nn, 2011). Zaenal's statement, which requires religious nuances, does not end there. Zaenal also ensures that "if the DUGI pair wins, the statues in Purwakarta will fall again. The basis said Zaenal again is "Amar Ma'ruf Nahi Munkar", inviting goodness and preventing evil. Zaenal also called on the DUGI masses not to be afraid to fight against the enemy (politics), even though, at first glance, they appear to be more numerous. "In the time of the prophet, there were only hundreds of Muslims who were able to win the war even though the number of enemies at that time 
reached 13,000 people. Said Zaenal, telling the story. The DUGI jurkam conveyed a similar expression from PKS (Nn, 2011).

\section{Attributes and campaign media associated with religion}

In the campaign process, candidates tend to include clerics, even some who use a robe or turban as a symbol associated with religion. The fact that religion is used as a potential channel for political da'wah in the Pilkada Purwakarta is the impact of a cultural transformation process based on changes in theological views that the people of Purwakarta understand.

The kyai or ustadz, as an Islamic religious leader, is seen as the most capable of interpreting the holy book (Effendi, 2020a) (Effendi, 2021c) so that with his charisma, he can determine the level of influence of a kyai. Candidates use the power of charisma for Regent and Deputy Regent of Purwakarta to influence and attract the masses with the character of a kyai as an elite group in society who has an essential power in Indonesian political life (Dhofier, 1982). Even more broadly, Endang Turmudi referred to Kyai as part of the political elite (Turmudi, 2003). The involvement of kyai in the political stage can also be seen during the period of physical resistance to expel the invaders and in activities in the form of diplomacy, both before and after independence was proclaimed.

The informants' words can be interpreted as a form of issue, and the issue is closely related to the language of religion. As John Dewey said that every human action has consequences for others, these consequences can affect people directly involved in political communication transactions and who affect other people outside the direct interest (Nimmo, 2010). Thus, an issue becomes common if the conflict causes the issue to reach beyond the parties directly involved.

The use of these issues is part of political communication, which is an essential means of shaping public opinion and dynamizing social life to achieve the goals it has set. The use of religious issues as expressed by informants is often used by interested groups, especially candidates and the success team for the Regent and Deputy Regent of Purwakarta, to create an individual image and bring down political opponents (Saepudin, 2012).

If you look at statements related to the intersection of religion and politics, Asep Saiful Muhtadi gives two reasons why religious themes are chosen as a vehicle for political communication. First, religion is the central identity that binds the solidarity of supporters of the candidate pair who have a Muslim community constituency base. Second, the reason 
for the background of the religious community in Purwakarta, especially the majority of Muslims, so that sociologically religion is a sensitive instrument that can become a crucial tool for society, as well as a source of differences that can trigger conflict (Effendi, 2021a; Muhtadi, 2008).

Seeing the reading of the political map in the Purwakarta Pilkada, one candidate pair used it to serve as public opinion and image. However, in reality, not as expected, the use of religious issues in the Pilkada Purwakarta did not affect most of the people of Purwakarta as voters or voters. This is because the public as voters in the Pilkada Purwakarta can be classified according to the typical voters and their political behaviour due to political communication made by the candidate to the community.

\section{The Impact of the Pilkada of Purwakarta Regency}

Political communication during the Pilkada Purwakarta did not rule out the possibility of various impacts or potential consequences cognitively, affectively and conatively or behaviorally (Muhtadi, 2008). In the implementation of campaigns, for example, it tends to be done by selling symbols of primordiality such as religious figures or colours, and not the program and capacity of the party to realize the promised programs (Maliki, 2010). So that in the end, the campaign was permanently coloured with acts of violence and even led to elements of SARA. During the campaign, the social control of the apparatus became weak, and it was used as an opportunity for the public to express their disappointment openly. The practice of violence as a form of pent-up disappointment like this has been proven in the Pilkada Purwkarta, even in several elections that took place in several regions such as the West Java Gubernatorial Election (Governor Election), West Bandung Regency Pilkada and Subang Pilkada, which the authors monitored even though in the context of the issue. Different ones.

In the Purwakarta Pilkada campaign, there was indeed violence that contained elements of SARA, as stated by several informants even according to Jalaluddin, "there was physical violence as a result of an infidel-infidel verbal argument between supporters of the Regent and Deputy Regent candidates in Purwakarta during the campaign" (Jalaludin, 2013). In this case, we can use the explanation of Robert T. Gurr (1974) regarding the theory of relative deprivation, the occurrence of such violence is caused by people who are affected 
by relative deprivation so that it will be easy to be tempted to commit acts of violence, and use any instrument that is considered to be able to support it. (Gurr, 1997)

Not only that, the campaigns carried out by each pair of candidates for the RegentDeputy Regent of Purwakarta sometimes also led to excessive fanaticism. As revealed by Didin Syaprudin when met at his office, explaining that there were public reports of allegations (Syaprudin, 2012),

"SAHATE's covert campaign was carried out in the Munjul Jaya scenic area, so that suddenly the people who were dominant against the incumbent candidate SAHATE shouted loudly and even blasphemed him, to the point that a dalmas containing members of the National Police was dispatched to defuse the situation at that time."

Campaign with mass mobilization is the best instrument to express disappointment. Following the characteristics of the "anonymous" masses, loss of sense of responsibility and personal awareness will quickly emerge at that time-sensitive and emotional friendship solidarity (Maliki, 2010). As a result, collective violence, mass protests and security threats occurred in the Purwakarta Pilkada.

The occurrence of violence in the Pilkada Purwakarta because one of the root causes of the problem began with the erection of statues by the incumbent candidate SAHATE, which eventually led to mutual disbelief, until one day Andris Hadiansyah heard (Hadiansyah, 2012),

"There are people who say that the incumbent candidate is not a Muslim. This can be seen from one of the events or a thousand tumpeng parade held by the incumbent candidate, which is similar to Hinduism".

The pair of candidates for the Regent/Deputy Regent of Purwakarta promoted by the "SAHATE" coalition, namely the pair Dedi Mulyadi/Dadan Koswara, officially won the political battle in the 2012 post-conflict local election of Purwakarta Regency by obtaining a total of 306,332 votes (63.35 per cent). The vote gain was followed by the DUGI pair (Dudung B. Supardi/ Yogie Mochammad) with 115,689 votes (23.93 per cent) and the BOMBER pair (Burhan Fuad/ Onie S. Sandi) with 44,646 votes (9.23 per cent) (Haidar, 2012).

The vote acquisition for the SAHATE pair was not much different from the release from Cikom-LSI on December 15 in the afternoon, which stated that the Sahate pair was superior with 65.55 per cent of the votes, ahead of the Dudung pair. B. Supardi-Yogie 
Mochammad (DUGI), who received 24.72\% of the votes and third place pair Burhan FuadOnie S. Sandi (BOMBER) received $9.73 \%$ of the votes.

Although the results of the KPU's official calculations have been determined, the Sahate couple does not seem to be able to walk kangkung. The reason is, the two opposing camps, namely the Dudung-Yogie and Burhan-Onie pair, filed a lawsuit to the Constitutional Court.

However, the lawsuit is not to challenge the results of the KPUD recapitulation, but the two camps against Dedi think that the SAHATE coalition has committed too much fraud, namely the Dedi Mulyadi-Dadan Koswara pair before and on the D day of the Pilkada. The opposing camp proved dissatisfaction with the results of the post-conflict local election by not signing the official report on the results of the recapitulation of the KPUD. Even the team of witnesses from the Burhan-Onnie pair took a "walkout" action before the Chairperson of KPUD Deni Ahmad Haidar would read the agenda for the event at that time. Furthermore, this was confirmed by the witnesses who attended the determination of the recapitulation of the results of the regional head election for the Regent and Deputy Regent of Purwakarta.

Disappointment over the results of the vote by the DUGI and BOMBER coalition over their rival SAHATE was taken through legal proceedings to the Constitutional Court of the Republic of Indonesia. Didin Syaprudin also justified the actions taken by the disappointed camp, and he explained that (Syaprudin, 2012):

"The reason for the supporters of the DUGI and BOMBER coalitions suing SAHATE is not because of the results of the vote, but because of the alleged fraud committed by the SAHATE coalition, primarily until the voting day is carried out. Even though Panwas has called the plaintiff to discuss the evidence of the violation in question, whether it is a violation of the code of ethics or a criminal offence. However, when it was explained that the plaintiff insisted that he did not accept the Panwas of Purwakarta Regency's answer, the plaintiff filed a lawsuit to the Constitutional Court on the decision of the Purwakarta KPUD.

Apart from that, the victory of SAHATE, who is the incumbent candidate in the Pilkada Purwakarta, is an answer that the large flow of religious issues that exist only has little influence on constituents as voters. Moreover, said Aa Ojat Sudrajat, who is also the chairman of BAPPILU for winning the SAHATE team revealed (Sudrajat, 2012),

"SAHATE's victory is the victory of the people of Purwakarta. The people of Purwakarta are smart and can feel the impact of the leadership of the incumbent Regent candidate so that the influence of religious issues used by one candidate pair does not have a major impact on the votes of constituents as voters". 
The phenomenon of religious involvement in Pilkada politics can be realized by various symbols, actors and statements related to religion. This kind of phenomenon becomes essential in the context of regional autonomy and the Pilkada as a strategy to build democracy in local communities (Effendi, 2020b; Kahmad, 2011b). The influence of religion is evident in the current era of regional autonomy, especially in the Pilkada of Purwakarta Regency. This kind of fact can also be seen from the history of Indonesian politics when religion played or was played as a political force (Kahmad, 2011b).

The practice of using religious issues in politics varies significantly in terms of symbols, places, and statements used. In this context, religious issues in campaigns are based on the belief that the public will give their political choices to pairs of candidates who have excellent and correct religious qualities. For this reason, each pair of candidates tries to image themselves as religious, even if necessary to manipulate them (Kahmad, 2011b). However much politics can play the role of religion in people's lives, politics will continue to give birth to conflicts or disagreements. It is just that the temperature of the conflict sometimes weakens and sometimes strengthens, depending on political dynamics, where the ruling party's behaviour towards his political opponent will determine the temperature of the conflict (Mintarja, 2011).

\section{Conclusion}

As formulated in the focus of this research study, it can be concluded that: First, the presence of religion in politics as happened in the Pilkada Purwakarta, there are two views of the public about whether or not religious issues are used as political tools for candidates. A small number of them think that the issues made by the candidates in political campaigns tend not to describe the use of religion in the name of religion. They use it because most people question the establishment of statues in Purwakarta, as often addressed by Muslims, have absolutely nothing to do with religion, but it occurs due to people's ignorance of culture and art itself. Statements like this are incredibly widely expressed. By the non-Muslim community, even among Muslims themselves have the same opinion. Then most of them agreed with the use of religious issues in the Pilkada Purwakarta, including the issue of statues which were considered a new form of idolization and hinted at the occurrence of polytheism by the Incumbent SAHATE candidate, besides that long before the Pilkada, the behaviour of the SAHATE Incumbent candidate had been several times he committed blasphemy against religion, Islam in particular, such as the case of positioning the Qur'an 
which is considered the same as the flute and harp so that the implementation of the Pilkada is often coloured by blasphemy among the supporters of each candidate in particular.

Second, the use of issues based on religion is evidence to justify that religion and politics cannot be separated. Both complement each other, even though religion and politics have characteristics that can distinguish the two. Among the religious issues used in the Pilkada Purwakarta could be the use of religious symbols, statements, figures and places used by the contestants and political constituents in Purwakarta. This can be seen from several typologies of issues based on religion in the Pilkada of the Regent and Deputy Regent of Purwakarta Regency.

Among the many issues, the one that attracts attention and is even dominant is related to the use of religious elements, which are normatively used as weapons for candidates. Therefore, this shows that socio-political movements that use religion as a commodity to attract the sympathy of the masses and create sources of issues or highlight a particular group, or vice versa, are other things in religion to continue to exist in political struggles.

\section{Bibliography}

(terj.), M. W. A. Q. S. (2012). Essay from Max Weber (Terj.Teori Dasar Analisis Kebudayaan). Ircisod.

Al-Ghifari, F. (2013). Wawancara Mendalam.

Amidin, A. (2013). Wawancara Mendalam.

Dhofier, Z. (1982). Tradisi Pesantren; Suatu Studi tentang Peranan Kyai dalam Memelihara dan Mengembangkan Ideology Islam Tradisional”. LP3ES.

Effendi, M. R. (2020a). Mitigasi Intoleransi dan Radikalisme Beragama di Pondok Pesantren Melalui Pendekatan Pembelajaran Inklusif. Paedagogie, I(I), 55-74. https://doi.org/doi.org/10.20211/pdg.01.1.05

Effendi, M. R. (2020b). Pertalian Agama dalam Pilkada DKI Jakarta Tahun 2017. Jurnal Mibar Demokrasi, 19(2), 12-27. https://doi.org/10.21009/jimd.v19i02.14528

Effendi, M. R. (2021a). Relasi Agama dan Masyarakat; Studi Tentang Interaksi Masyarakat Bandung Barat dan Jamaah Tabligh. Hayula, 5(1), 1-24. https://doi.org/https://doi.org/10.21009/hayula.005.1

Effendi, M. R. (2021b). Sosiologi Pendidikan; Analisis dan Wacan Pendidikan di Era 4.0. Pustaka Learning Center. 
Effendi, M. R. (2021c). Teologi Islam; Potret Sejarah dan Perkembangan Mazhab Kalam. Literasi Nusantara.

Effendy, B. (2000). Re-Politisasi Islam; Pernahkah Islam berhenti Berpolitik? (A. S. Sudajat (ed.)). Mizan.

Fukuyama, F. (2007). The End of History and The Last Man; Kemenangan Kapitalisme dan Demokrasi Liberal. Qalam.

Grose, G. B. (1998). The Abraham Connection: A Jew, Christian an Muslim in Dialogue (terj.) Tiga Agama Satu Tuhan; Sebuah Dialog (S. I. Astuti (ed.)). Mizan.

Gurr, R. T. (1997). Why Man Rebel. Pricenton University Press.

Hadiansyah, A. (2012). Wawancara Mendalam.

Haidar, D. A. (2012). Wawancara Mendalam.

Hanani, S. (2011). Menggali Interelasi Sosiologi dan Agama. Humaniora.

Jalaludin. (2013). Wawancara Mendalam.

Jung, C. G. (1964). Man and his Symbol. Aldus Books Ltd.

Kahmad, D. (2011a). Metode Penelitian Agama; Persepektif Ilmu Perbandingan Agama. Pustaka Setia.

Kahmad, D. (2011b). Sosiologi Agama; Potret Agama dalam Dinamika Konflik, Pluralisme dan Modernitas. Pustaka Setia.

Kamarulzaman, A. (2005). Kamus ilmiah Serapan Bahasa Indonesia. Absolut.

Lippman, W. (1998). Opini Umum, S. Maimoen (terj.). Yayasan Obor.

Maliki, Z. (2010). Sosiologi Politik; Makna Kekuasaan dan Transformasi Politik. UGM Press.

Mukhlis, C. (2008). Membenahi Manajemen Pemilu. Tasikmalaya: KPU.

Mintarja, E. (2011). Politik Berbasis Agama. Remaja Rosdakarya.

Muchlis, C. (2008). Membenahi Manajemen Pemilu. KPUD Tasikmalaya.

Muhtadi, A. S. (2008). Komunikasi Politik Indonesia; Dinamika Islam Politik Pasca Orde Baru. Remaja Rosdakarya.

Nata, A. (2012). Wawancara Mendalam. 
Nimmo, D. (2010). Komunikasi Politik: Khalayak dan Efek. Remaja Rosdakarya.

Nn. (2011). Patung Bima Dirobohkan. Radar Karawang, 16.

Pujianti, C. (2013). Wawancara Mendalam.

Purnama, E. S. (2012). Wawancara Mendalam.

Razak, A. A. (2012). Wawancara Mendalam.

Rohendi. (2012). Wawancara Mendalam.

Saepudin, A. (2012). Wawancara Mendalam.

Smith, D. E. (1985). Agama dan Modernisasi Politik; Suatu Kajian Analitis (M. Hussein (ed.)). Rajawali Press.

Statistik, B. P. (2015). Kabupaten Purwakarta Dalam Angka. BPS Purwakarta.

Sudrajat, A. O. (2012). Wawancara Mendalam.

Supriyanto. (2012). Wawancara Mendalam.

Syaprudin, D. (2012). Wawancara Mendalam.

Turmudi, E. (2003). Perselingkuhan Kiai dan Kekuasaan. LKiS.

Wardi, U. U. (2012). Wawancara Mendalam. 